\title{
Structural Performance of Automated Multi-Depth Shuttle Warehouses (Amsws) Under Low-to- Moderate Seismic Actions
}

\section{Research Article}

Keywords:

Posted Date: March 30th, 2021

DOI: https://doi.org/10.21203/rs.3.rs-351252/v2

License: (c) (1) This work is licensed under a Creative Commons Attribution 4.0 International License. Read Full License

Version of Record: A version of this preprint was published at Bulletin of Earthquake Engineering on October 26th, 2021. See the published version at https://doi.org/10.1007/s10518-021-01193-y. 


\section{Abstract}

The authors have requested that this preprint be withdrawn due to erroneous posting.

\section{Full Text}

The authors have withdrawn this preprint from Research Square. 